\title{
Comparison of Maternal Health Service Satisfaction Level of National Health Coverage and Non National Health Coverage Patients in Bandung Mother and Child Hospital
}

\author{
Rika Yuntiani, ${ }^{1}$ Eppy Darmadi Achmad, ${ }^{2}$ Henni Djuhaeni ${ }^{3}$ \\ ${ }^{1}$ Faculty of Medicine Universitas Padjadjaran, ${ }^{2}$ Department of Obstetric and Gynecology Faculty \\ of Medicine Universitas Padjadjaran/Dr. Hasan Sadikin General Hospital, Bandung, ${ }^{3}$ Department \\ of Public Health Faculty of Medicine Universitas Padjadjaran
}

\begin{abstract}
Background: Healthcare is financially inaccessible to some people. This results in deterioration of patients' condition or even death, which is proven by the high level of Maternal Death Rate in Indonesia. The government implemented the National Health Coverage (NHC) system to ensure the provision of quality health care for the entire community. This study aimed to examine the NHC and non-NHC patients' perception to quality maternal healthcare services.

Methods: This study was an analytic cross-sectional study conducted from August-October 2014. One hundred and twenty six respondents from Kota Bandung Mother and Child Hospital were included. The tool used in this study was a validity and reliability-tested questionnaire encompassing five dimensions of service quality: tangibles, reliability, responsiveness, assurance, and empathy. The Kolmogorov-Smirnov test was used to test the hypothesis.

Results: The study showed that the majority of NHC(75\%) and non-NHC patients (89\%) ware unsatisfied with the maternal healthcare services. Most patients felt unsatisfied towards the reliability dimension which involved complicated referral procedures and examination time that failed to comply with what was promised.

Conclusions: There is no difference between NHC and non-NHC patients' level of satisfaction of maternal health care service in Bandung Mother and Child Hospital. [AMJ.2016;3(3):425-29]
\end{abstract}

Keywords: National health coverage, maternal health, satisfaction

\section{Introduction}

Health care service that is not readily available financially has caused some parts of the community are unable to get suitable care. This causes the patient's condition to worsen or even death, which is reflected by the high number of Maternal Mortality Rate (MMR) in Indonesia. In West Java in 2007, the MMR was 95.81 per 100,000 live births; while in Bandung it was 20 per 36,122 live births. ${ }^{1}$ The government started the Jaminan Kesehatan Nasional (National Health Coverage-NHC) system on 1 January 2014 which covered maternal care. The Universal health coverage and NHC aim to ensure all Indonesians of quality health care without any financial risk. ${ }^{2,3}$ One of the indicators for health care quality is patient's satisfaction. ${ }^{4,5}$ Satisfaction over the services is determined by the patient's perception of the quality of service which comprises of five dimensions: tangibles, reliability, responsiveness, assurance, and empathy. ${ }^{6}$ A study by Dalinjong and Laars ${ }^{7}$ and Fenny ${ }^{8}$ in Ghana showed that both Universal Health Coverage (UHC) clients and non-clients feel satisfied with the service they receive.

Bandung Mother and Child Hospital is a public hospital which handles advanced maternal problems and has already implemented the NHC system. This study was aimed to find out the difference in levels of satisfaction between NHC and non-NHC patients over maternal health care service in Bandung Mother and Child Hospital.

\section{Methods}

This analytic cross-sectional study was carried out in Bandung Mother and Child Hospital

Correspondence: Rika Yuntiani, Faculty of Medicine, Universitas Padjadjaran, Jalan Raya Bandung-Sumedang Km.21, Jatinangor, Sumedang, Indonesia, Phone: +62 85759866015 Email: rikayuntiani@gmail.com 
from August-October 2014, and it had been approved by the Health Research Ethics Committee, Faculty of Medicine Universitas Padjadjaran.

The population of this study was all maternal patients of the Obstetrics and Gynecology Polyclinic. The subjects were selected by consecutive sampling, including NHC and non-NHC outpatients. The minimum sample size required was 104 people. The subjects enrolled in this study were nonaid-awardee (non-Penerima Bantuan Iuran) NHC patients and non-NHC patients who had experienced maternal health care service at least once. Subjects who failed to complete the questionnaire or were unwilling to participate in the study were excluded, 134 respondents were selected, but there were 5 incomplete questionnaires and 3 first-time visitors, as such the total samples comprised of 126 respondents.

The variable measured in this study was the patient's satisfaction. Satisfaction is measured based on the patient's perception of the quality of service which comprises of five dimensions: tangibles, reliability, responsiveness, assurance, and empathy. The data was collected by using the satisfaction questionnaire whose validity and reliability had been tested. The questionnaire was made up of 25 questions with 5 topics according to the dimensions of service. The questionnaire asked the patient's expectations and real experience, each was valued from 1 to 4 . The satisfaction score was calculated by determining the gap between the expectations and real experience. Satisfaction

Table 1 Respondent's Characteristics

\begin{tabular}{|c|c|c|c|c|}
\hline \multirow{2}{*}{ Characteristics } & \multicolumn{2}{|c|}{ NHC } & \multicolumn{2}{|c|}{ Non-NHC } \\
\hline & $\mathbf{F}$ & $\%$ & $\mathbf{F}$ & $\%$ \\
\hline \multicolumn{5}{|l|}{ Age (years) } \\
\hline $15-20$ & 2 & 3 & 2 & 3 \\
\hline $21-25$ & 11 & 18 & 16 & 25 \\
\hline $26-30$ & 16 & 25 & 19 & 30 \\
\hline $31-35$ & 20 & 32 & 12 & 19 \\
\hline $36-40$ & 10 & 16 & 11 & 18 \\
\hline $41-45$ & 4 & 6 & 3 & 5 \\
\hline \multicolumn{5}{|l|}{ Education } \\
\hline Elementary school & 4 & 6 & 5 & 8 \\
\hline Middle school/ equal & 13 & 21 & 9 & 14 \\
\hline High school/equal & 37 & 59 & 41 & 65 \\
\hline Higher education & 9 & 14 & 8 & 13 \\
\hline \multicolumn{5}{|l|}{ Occupation } \\
\hline Housewife & 50 & 80 & 48 & 76 \\
\hline Self-employed & 4 & 6 & 3 & 5 \\
\hline Employee & 9 & 14 & 8 & 13 \\
\hline Teacher & 0 & 0 & 2 & 3 \\
\hline Others & 0 & 0 & 2 & 3 \\
\hline \multicolumn{5}{|l|}{ Service Grade(NHC) } \\
\hline Grade I & 11 & 18 & & \\
\hline Grade II & 21 & 33 & & \\
\hline Grade III & 31 & 49 & & \\
\hline Total & 63 & 100 & 63 & 100 \\
\hline
\end{tabular}

Note: *NHC: National Health Coverage (Jaminan Kesehatan Nasional) 
Rika Yuntiani, Eppy Darmadi Achmad, Henni Djuhaeni: Comparison of Maternal Health Service Satisfaction 427 Level of National Health Coverage and Non National Health Coverage Patients

Table 2 Patient's Level of Satisfaction over Maternal Health Service

\begin{tabular}{|c|c|c|c|c|c|c|c|c|}
\hline & & \multicolumn{6}{|c|}{ Satisfaction Level } & \multirow{3}{*}{$\mathbf{p}$} \\
\hline & & \multicolumn{2}{|c|}{ Highly Satisfied } & \multicolumn{2}{|c|}{ Satisfied } & \multicolumn{2}{|c|}{ Unsatisfied } & \\
\hline & & $\mathbf{n}$ & $\%$ & $\mathbf{n}$ & $\%$ & $\mathbf{n}$ & $\%$ & \\
\hline \multirow[t]{2}{*}{ Type of Funding } & NHC & 6 & 9 & 10 & 16 & 47 & 75 & 0.541 \\
\hline & Non-NHC & 2 & 3 & 5 & 8 & 56 & 89 & \\
\hline
\end{tabular}

Note: *NHC: National Health Coverage Uaminan Kesehatan Nasional)

was achieved if there was no gap. The smaller the gap was (or the more negative it was), the higher the patient's level of satisfaction was, and vice versa.

Furthermore, the collected data was analyzed with computer. Normality test was not performed because the data were either nominal or ordinal in nature. The KolmogorovSmirnov test was used because the data did not fulfill the requirement for using the ChiSquared test. The analysis was performed to find out the difference in satisfaction level between NHC and non-NHC patients. The result was interpreted by looking at the p-value: null hypothesis would be rejected if p-value was less than 0.05 and vice versa.

\section{Result}

The subject's characteristics examined in this study were age, education, occupation, and the service grade chosen by NHC respondents. For details, refer to Table 1 .

The majority of the NHC respondents in this study were mothers 31-35 years of age while for the non-NHC respondents, most were 26-30 years of age. The most prominent educational level of the respondents from both groups was high school or the equal. The majority of the respondents were housewives with no occupation. Almost 50\% of JNK respondents chose grade III service which required a monthly fee of Rp25,500.00 (Table 1).

The difference in the levels of satisfaction between NHC and non-NHC patients regarding maternal health care service showed thatthe respondents from both groups declared unsatisfied by the maternal health care service; the difference between the proportions of the each group was insignificant (Table 2).

Moreover, most respondents from either group were unsatisfied with all the service dimensions, with highest number of unsatisfied patients were discovered in the Reliability dimension. There was a difference in the proportion of level of satisfaction between

Table 3 Level of Satisfaction over 5 Service Dimensions



Note: *NHC: National Health Coverage (Jaminan Kesehatan Nasional) 
NHC and non-NHC respondents; however, the difference was insignificant (Table 3).

Meanwhile, about $73 \%$ of NHC respondents concurred that there had been improvement in the service quality, where they perceived a better service after the implementation of NHC. The other $23 \%$ did not perceive any difference in service quality even after the implementation of NHC.

\section{Discussion}

In overall, this study discovered that most patients, both NHC and non-NHC, were unsatisfied by the maternal health care service in Kota Bandung Mother and Child Hospital. This finding was not in agreement with a study by Dalinjong and Laars ${ }^{7}$ and Fenny ${ }^{8}$ which discovered that both NHIS (National Health Insurance Scheme) and non-NHIS patients in Ghana express satisfaction over the service they receive. The service quality is one of the factors that determine patient's satisfaction. ${ }^{4}$ Satisfaction can be achieved if the patient experienced the service they expect; therefore, it reflected that Kota Bandung Mother and Child Hospital must improve its service quality so as to achieve the patient's satisfaction.

The result showed that there was a difference in the size of the proportion with respect to the respondent's satisfaction: the proportion of the unsatisfied respondents was larger in the non-NHC group compared to the NHC group. This was also not in agreement with the finding of Dalinjong which states that the proportion of satisfied patients is higher in non-insurance patients than in insured patients. ${ }^{7}$ Moreover, most NHC respondents perceived a better service after the NHC implementation, expressing their relief concerning financial problems. This was appropriate with the objective of the NHC in Indonesia, which is to provide the whole country with health care service without risks of financial difficulties. This finding was different with a study by Volp which states that how the service is given to the patient has a larger influence on the patient's perception of service quality than less financial cost. ${ }^{9}$

The difference in the above-mentioned proportion was further analyzed, giving rise to p-value of 0.541, which deemed the particular proportion insignificant. This was congruent to the finding of Dalinjong and Laars ${ }^{7}$ and Fenny ${ }^{8}$ which states that the difference in level of satisfaction between insured and non-insured patients in Ghana is insignificant. Another study by Devadasan et al. ${ }^{10}$ in India also produced the same finding of no significant difference in the level of satisfaction between insured and non-insured patients under the Community Health Insurance scheme.

Furthermore, Parasuraman in Satsanguan ${ }^{6}$ states that service quality can be measured in 5 major dimensions: Tangible, Reliability, Responsiveness, Assurance, and Empathy. A study by Mosahab et al. ${ }^{4}$ also shows a significant correlation between the 5 service dimensions and patient's satisfaction, in which assurance and tangible have respectively the most and the least correlation to the patient's satisfaction. This study discovered insignificant difference in the proportion of the level of satisfaction in each dimension, unlike a study by Syahdat et al. ${ }^{11}$ involving general and ASKES patients which discovered significant difference in the Responsiveness and Tangibles dimensions, and insignificant difference in the Reliability, Assurance, and Empathy dimensions.

The dimension of Reliability, which involved the experience of receiving suitable service in the promised time, was the dimension with the highest proportion of dissatisfaction. This was caused by the large number of NHC patients complaining about complicated referral procedures and the long waiting time prior to examination by a doctor which failed to comply with the promised meeting for examination. Other dimensions with high proportions of dissatisfaction are Tangible and Responsiveness; Tangible involved the condition of the administration room, waiting room, examination room, and pharmacy, and the availability of the examination instruments. While Responsiveness involved the responsiveness of health care providers in meeting the patient's needs and appropriate waiting time. This was caused by the large number of visiting patients which led to crowded waiting and administration rooms and long waiting time prior to receiving the service.

Assurance and Empathy were the dimensions with the largest proportions of satisfaction. Both dimensions involved interpersonal relationships that had an instrumental role in determining patient's level of satisfaction, including the doctor-patient interaction and the attitude and attention given by other health workers. ${ }^{8}$ Larson and Yao $^{12}$ states that as empathy is very essential for quality care, the healing relationship between physicians and patients is important as well. Asefa et al. ${ }^{13}$ and Rao et al..$^{14}$ showed that patient's satisfaction is related to financial 
and interpersonal factors.

Based on the results and discussion above, it could be concluded that there was no significant difference in the level of satisfaction over maternal health care service between NHC and non-NHC patients in Kota Bandung Mother and Child Hospital. The limitations of this study were insufficient time, which prevented the inclusion of other factors which might be confounding variables such as family income, transportation cost, level of education, age and other socio-demographic factors. A study by Quintana et al. ${ }^{15}$ states that there are several factors with relation to satisfaction, which include socio-demographic variables and length of stay, previous admission, and the timing of response to the questionnaire. It is recommended that further studies take into account other factors that can influence the patient's level of satisfaction.

The result of this study can hopefully be an evaluative material for Kota Bandung Mother and Child Hospital to improve its maternal health care services so as to achieve satisfaction of each patient. The service dimensions requiring more attention are Tangible, Reliability, and Responsiveness. Badan Penyelenggara Jaminan Sosial (BPJS) has to do further evaluation on the service quality in the NHC era in other health care facilities in order to gain materials for consideration so that the quality of NHC-covered health care service can be improved, bringing Indonesia closer to an ideal Universal Health Coverage.

\section{References}

1. Dinas Kesehatan Jawa Barat. Profil kesehatan provinsi Jawa Barat tahun 2007. Bandung: Dinas Kesehatan Provinsi Jabar; 2008.

2. Kieny M-P, Evans DB. Universal health coverage. East Mediterr Health J. 2013;19(5):305-6.

3. Republik Indonesia. Undang-undang Republik Indonesia Nomor 40 Tahun 2004 Tentang Sistem Jaminan Sosial Nasional. Jakarta: Republik Indonesia; 2004.

4. Mosahab R, Mahamad O, Ramayah T. Service quality, customer satisfaction and loyalty: a test of mediation. International Bussiness Research. 2010;3(4):72-80.
5. Aldebasi YH, Ahmed MI. Patient's satisfaction with medical services in the Qassim area. J Clin Diagn Res. 2011;5(4):813-7.

6. Satsanguan L, Fongsuwan W, Trimetsoontorn J. Structural equation modelling of service quality and corporate image that affect customer satisfaction in private nursing homes in the Bangkok metropolitan region. Res J Bus Manag. 2015;9(1):68-87.

7. Dalinjong PA, Laar AS. The national health insurance scheme: perceptions and experiences of health care providers and clients in two districts of Ghana. Health economics review. 2012;2(1):1-13.

8. Fenny AP, Enemark U, Asante FA, Hansen KS. Patient satisfaction with primary health care-a comparison between the insured and non-insured under the national health insurance policy in Ghana. Glob J Health Sci. 2014;6(4):9-21.

9. Volpp KG. Designing a model health care system. Am J Public Health. 2007;97(12):2126-8.

10. Devadasan N, Criel B, Van Damme W, Lefevre P, Manoharan S, Van der Stuyft P. Community health insurance schemes \& patient satisfaction-evidence from India. Indian J Med Res. 2011;133(1):40-49.

11. Syahdat Nurkholiq, Suharto, Hari Peni Julianti, Ani Margawati. Perbandingan tingkat kepuasan pasien umum dengan pengguna kartu askes di pelayanan dokter keluarga PT. Askes. Semarang: Diponegoro University; 2011.

12. Larson EB, Yao $X$. Clinical empathy as emotional labor in the patient-physician relationship. JAMA. 2005;293(9):1100-6.

13. Asefa A, Kassa A, Dessalegn M. Patient satisfaction with outpatient health services in Hawassa University Teaching Hospital, Southern Ethiopia. J Public Health Epidemiol. 2014;6(2):101-10.

14. Rao KD, Peters DH, Bandeen-Roche K. Towards patient-centered health services in India-a scale to measure patient perceptions of quality. Int J Qual Health Care. 2006;18(6):414-21.

15. Quintana JM, González N, Bilbao A, Aizpuru F, Escobar A, Esteban C, et al. Predictors of patient satisfaction with hospital health care. BMC Health Serv Res. 2006;6(1):102. 